\title{
Analisis Kapasitas Fiskal dan Pengeluaran Pemerintah terhadap Pertumbuhan Ekonomi dan Kesejahteraan Masyarakat Provinsi Kalimantan Tengah
}

\author{
Juma'eh $^{1,2^{*}}$, Harin Tiawon ${ }^{3}$, Alexandra Hukom ${ }^{3}$ \\ ${ }^{1}$ Badan Pengelola Keuangan dan Aset Daerah Kabupaten Kotawaringin Timur \\ ${ }^{2}$ Alumni Program Studi Magister Ilmu Ekonomi Universitas Palangka Raya \\ ${ }^{3}$ Dosen Program Studi Magister IImu Ekonomi Universitas Palangka Raya \\ *Korespondensi: Juma'eh (Email: hjumaeh@gmail.com)
}

\begin{abstract}
Decentralization of the government that passed since 2004 provides an opportunity to improve the welfare of the community if financial management is carried out effectively. Unfortunately, some regions failed to take advantage of this opportunity. This study aims at analyzing the effect of fiscal capacity and government spending on economic growth and social welfare in Central Kalimantan Province. Path analysis and multiple regression tests using IBM SPSS Version 25.0 are used to analyze government capital expenditure and economic growth in 2007-2017. The results show that fiscal capacity and government spending have a significant direct effect on economic growth. Fiscal capacity and government expenditure do not have a significant direct effect on economic growth, while economic growth has a significant direct effect on economic growth. Meanwhile, fiscal capacity and government spending have a significant indirect effect on the welfare of the community through economic growth in the province of Central Kalimantan in the 2010-2017 period. In addition, efforts to increase sources of the regional revenue, mainly local revenue, are needed to increase regional financial independence in the implementation of regional autonomy and to enhance economic growth.
\end{abstract}

\section{Keywords}

Fiscal capacity, government expenditure, economic growth, human development index, Central Kalimantan

\section{PENDAhUluan}

Pertumbuhan ekonomi dengan adanya kestabilan perekonomian domestik yang baik merupakan tujuan utama yang ingin dicapai oleh setiap negara melalui adanya kebijakan ekonomi. Pertumbuhan ekonomi suatu daerah diharapkan dapat meningkatkan kesejahteraan masyarakat, karena dapat membangkitkan sektor-sektor ekonomi produktif seperti ketersediaan sektor-sektor lapangan usaha melalui penggunaan faktor-faktor produksi yang akan menghasilkan barang maupun jasa (Sanjaya et al., 2017).

Dengan berlakunya Undang-Undang Nomor 23 Tahun 2014 tentang Pemerintahan Daerah, sebagai upaya upaya untuk mendukung pelaksanaan otonomi daerah, efisiensi penggunaan keuangan negara, serta prinsip-prinsip pemerintahan yang baik (good governance), melalui konsep partisipasi, transparansi, dan akuntabilitas (Surtikanti, 2004). Konsep utama dalam pelaksanaan perimbangan keuangan tersebut adalah melalui desentralisasi fiskal, bahwa untuk mendukung penyelenggaraan otonomi daerah yang luas, nyata dan bertanggung jawab. Untuk itu daerah mempunyai kewenangan yang lebih luas dalam memanfaatkan sumber penerimaaannya sendiri melalui dukungan perimbangan keuangan antara pusat dan daerah (Banga, 2017).

Beberapa daerah memiliki rasio kemandirian fiskal tinggi, sedangkan sebagian besar lainnya masih bergantung pada transfer pemerintah pusat. Proporsi dana transfer ke daerah masih didominasi oleh Dana Alokasi Umum (DAU), dan terbesar kedua adalah Dana Alokasi Khusus (DAK), dan kemudian di ikuti oleh Dana Bagi Hasil (DBH). Anggaran Pendapatan dan Belanja Daerah (APBD) memiliki peran penting dalam menjalankan fungsi pemerintahan daerah untuk menyediakan layanan masyarakat, sekaligus menjadi instrumen fiskal di daerah. Banga (2017) mengemukakan bahwa peran tersebut semakin menguat pada era desentralisasi fiskal. Hal ini memunculkan konsekuensi 
kuat dalam kerangka akuntabilitas, transparansi dan pertanggungjawaban APBD. Pelaksanaan fungsi pemerintahan daerah dapat berjalan baik, apabila didukung dengan pendapatan yang memadai. APBD merefleksikan arah pencapaian tujuan visi dan misi yang ditetapkan oleh daerah. Hakikat misi daerah ditujukan untuk kemajuan ekonomi yang lebih baik. Realisasi dan pengalokasian dana melalui APBD merefleksikan kinerja pengelolaan keuangan daerah. APBD juga berfungsi sebagai pedoman penerimaan dan pengeluaran daerah yang sehat akan memberikan dampak positif terhadap kemudahan layanan masyarakat dan aksesibilitas dalam rangka meningkatkan pertumbuhan ekonomi daerah yang akan berdampak terhadap peningkatan kesejahteraan masyarakat (Putra, 2018). Seiring dengan regulasi tersebut, pemerintah daerah dituntut dapat mendayagunakan sumber daya dan potensi daerah untuk tujuan pembangunan daerah melalaui pengelolaan APBD yang efektif dan produktif dengan mengurangi belanja konsumtif, meningkatkan PAD dan memperbesar alokasi belanja modal guna mendorong percepatan pembangunan daerah dan peningkatan kesejahteraan masyarakat (Sumardjoko, 2017).

Perkembangan kapasitas fiskal, pengeluaran pemerintah, pertumbuhan ekonomi dan kesejahteraan masyarakat yang di proksi ke dalam indeks pembangunan manusia di Provinsi Kalimantan Tengah dalam periode tahun 2010-2017 adalah sebagai berikut. Berdasarkan yangg dipublikasikan oleh BPS dalam rentang tahun 2010-2017, perkembangan kapasitas fiskal menunjukkan trend fluktuatif dengan kecenderungan menurun dari daerah dengan indeks kapasitas fiskal tinggi $(1,47)$ pada tahun 2010 menjadi daerah dengan indeks kapasitas fiskal sedang $(0,61)$ pada tahun 2017. Demikian juga pengeluaran pemerintah melalui belanja modal menunjukkan trend yang fluktuatif dengan kecenderungan menurun. Pada tahun 2010 belanja modal pemerintah daerah adalah sebesar, Rp. 2,379 triliun meningkat menjadi Rp. 4,943 triliun (2015), kemudian mengalami penurunan sebesar Rp. 4,488 triliun menjadi Rp. 4,023 triliun (2017). Trend yang berbeda ditunjukkan oleh pertumbuhan ekonomi yang menunjukkan peningkatan yang positif dan stabil dalam kurun waktu 6 (enam) tahun terakhir dari Rp. 56,531 triliun (2010) meningkat menjadi Rp. 88,812 triliun (2017). Demikian juga dengan indeks pembangunan manusia (IPM) yang menunjukkan trend meningkat secara stabil dari 65,96 (2010) meningkat menjadi 69,79 (2017).

Hasil pengamatan pada penelitian terdahulu tentang pengaruh desentralisasi fiskal terhadap pertumbuhan ekonomi menunjukkan hasil yang beragam. Penelitian Lin dan Liu (2000), Sasana (2006), Iskandar (2012), Amanda (2017), Gavriluta (Vatamanu) dan Oprea (2017) menyimpulkan bahwa desentralisasi fiskal berpengaruh positif dan signifikan terhadap pertumbuhan ekonomi. Sementara penelitian yang dilakukan Zhang dan Zou (1998) dan Hendri (2015) bahwa desentralisasi fiskal berpengaruh negatif terhadap pertumbuhan ekonomi.

Beberapa hasil pengamatan terdahulu tentang pengeluaran pemerintah terhadap pertumbuhan ekonomi dan kesejahteraan masyarakat seperti yang dilakukan oleh Sasana (2012), Ndakularak et al. (2013) Anitasari dan Soleh (2015), dan Maingi (2017) menyatakan bahwa belanja pemerintah berpengaruh positif dan signifikan terhadap kesejahteraan masyarakat dan pertumbuhan ekonomi. Sementara, Olopade dan Olopade (2010), Iheanacho (2016), Sumardjoko (2017) dan Okombi (2018) menyatakan bahwa pengeluaran pemerintah tidak berpengaruh dan cenderung berpengaruh negatif terhadap pertumbuhan ekonomi.

Studi yang dilakukan ini bertujuan untuk menganalisis pengaruh kapasitas fiskal dan pengeluaran pemerintah yang di proksi ke dalam belanja modal terhadap pertumbuhan ekonomi dan kesejahteraan masyarakat yang di proksi ke dalam IPM di Provinsi Kalimantan Tengah dalam periode tahun 2010-2017. Penelitian ini juga diharapkan dapat memberikan solusi dalam pengelolaan keuangan daerah secara efektif untuk belanja publik sehingga dapat menstimulasi peningkatan pertumbuhan ekonomi dengan tujuan akhir adalah peningkatan kesejahteraan masyarakat melalui capaian pembangunan manusia di wiayah ini maupun di Indonesia.

\section{METODOLOGI}

Penelitian ini merupakan jenis penelitian kuantitatif dengan jenis pengumpulan data sekunder yang bersumber dari hasil publikasi yang dikeluarkan oleh Badan Pusat Statisttik (BPS) Provinsi Kalimantan Tengah berupa data time series tahun 2010-2017 dan cross section terhadap 14 kabupaten/kota di Provinsi Kalimantan Tengah. Dengan menggunakan bantuan program IBM SPSS 25. Model persamaan regresi pada studi ini adalah sebagai berikut.

$I P M_{i t}=\beta_{0}+\beta_{1} K F_{i t}+\beta_{2} P P_{i t}+\beta_{3} P E_{i t}+\varepsilon_{i t} \ldots \ldots \ldots \ldots . . .(1)$

Dimana:

IPM = variabel indeks pembangunan manusia atau IPM (angka)

$\mathrm{PP}=$ variabel pengeluaran pemerintah berupa belanja modal (rupiah)

$\mathrm{PE}$ = variabel pertumbuhan ekonomi berupa PDRB Atas Dasar Harga Konstan (rupiah)

$\beta_{0}=$ konstanta; $\beta_{1}, \beta_{2}, \beta_{3}$ adalah koefisien regresi; $;$ : kabupaten/kota

$\mathrm{t} \quad=$ tahun

$\varepsilon \quad=$ kesalahan penganggu (error term).

Berdasarkan persamaan tersebut di dapat disusun ke dalam suatu formula, yaitu $Y=\beta_{0}+b X_{1}+b X_{2}+b X_{3}$. Analisis data yang dilakukan dalam penelitian ini 
menggunakan analisis jalur (path analysis) dan uji regresi berganda untuk pengujian hipotesis dengan Uji Parsial, Uji Simultan dan Uji Determinasi (Gunawan, 2017).

\section{HASIL}

\subsection{Hasil Analisis}

Analisis jalur (path analysis) dilakukan untuk menguji hipotesis penelitian untuk mengetahui pengaruh langsung dan tidak langsung antara variabel kapasitas fiskal dan pengeluaran pemerintah (belanja modal) terhadap variabel pertumbuhan ekonomi dan kesejahteraan masyarakat yang di proksi ke dalam IPM pada Kabupaten/Kota di Provinsi Kalimantan Tengah dalam rentang waktu antara 2010-2017.

Tabel 1. Output Regresi Berganda

$\begin{array}{lll}\text { Formula } & : & \text { IPM }=67,075-0,367 \mathrm{KF}+ \\ & & 4,756 \mathrm{E}+12 \mathrm{PP}+4,508 \mathrm{E}+13 \mathrm{PE} \\ \text { t hitung } & : & (-0,186)(1,416)(3,654)^{*} \\ \text { t tabel } & : & 1,979 \\ \text { F hitung } & : & (10,046)^{\star} \\ \text { F tabel } & : & 2,678 \\ \mathrm{R}^{2} & : & 0,218=21,8 \%\end{array}$

Significance at level $5 \%$

\subsection{Uji Goodness of fit}

Uji $F$ atau uji koefisien regresi secara bersama-sama digunakan untuk mengetahui apakah secara bersamasama variabel independen berpengaruh signifikan terhadap variabel dependen. Dalam penelitian ini Uji $F$ dilakukan untuk mengetahui pengaruh variabel kapasitas fiskal dan pengeluaran pemerintah yang di proksi ke dalam belanja modal terhadap pertumbuhan ekonomi dan kesejahteraan masyarakat yang di proksi ke dalam indeks pembangunan manusia (IPM). Dari hasil uji ANOVA untuk uji secara simultan diketahui nilai signifikansi adalah 0,000 dengan nilai $F$ hitung 10,046 dan nilai $F$ tabel 2,678 . Dengan taraf $F$ hitung $(10,046)>$ nilai $F$ tabel $(2,678)$, maka memberikan informasi bahwa terdapat pengaruh yang positif dan signifikan antara variabel kapasitas fiskal, pengeluaran pemerintah, dan pertumbuhan ekonomi secara simultan terhadap IPM. Hal ini menandakan bahwa apabila ketiga variabel independen tersebut secara bersama-sama digabung, maka dapat berdampak bagi kenaikan capaian IPM.

\subsection{Uji Determinasi (R Square)}

Uji determinasi dalam regresi berganda digunakan untuk mengetahui persentase sumbangan yang diberikan oleh masing-masing variabel independen secara simultan kepada variabel dependen. Dalam penelitian ini, nilai koefisien determinasi digunakan untuk mengetahui sumbangan pengaruh dari variabel kapasitas fiskal, pengeluaran pemerintah melalui belanja modal dan pertumbuhan secara simultan terhadap variabel IPM. Dengan nilai rentang yang mendekati 1 menunjukkan bahwa koefisien determinasi dari model regresi yang di teliti mempunyai pengaruh yang semakin kuat terhadap model penelitian. Berdasarkan hasil analisis di peroleh nilai koefisien determinasi yaitu sebesar 0,218 atau sebesar 21,8\%. Hasil analisis tersebut menunjukkan bahwa sumbangan pengaruh variabel kapasitas fiskal, pengeluaran pemerintah melalui belanja modal dan pertumbuhan secara simultan yang digunakan dalam model penelitian dapat merepresentasikan variasi variabel IPM yaitu sebesar $21,8 \%$, sedangkan sisanya sebesar $78,2 \%$ dipengaruhi oleh model lain yang tidak di teliti atau di luar penelitian.

\subsection{Uji Hipotesis}

Uji $t$ atau uji koefisien regresi secara parsial digunakan untuk mengetahui apakah secara parsial variabel independen berpengaruh secara signifikan atau tidak terhadap variabel dependen. Uji parsial diketahui dengan melihat hasil output SPSS dari nilai $t$ hitung masing-masing variabel independen dengan membandingkan dengan nilai t tabel. Hasil analisis secara parsial yang terdiri dari variabel kapasitas fiskal $\left(X_{1}\right)$ memiliki nilai $t$ hitung sebesar $-5,855$ yang lebih besar dari nilai t tabel yaitu $-1,979$ dengan signifkansi sebesar 0,000 < dibandingkan dengan taraf signifikansi 0,05. Artinya kapasitas fiskal memiliki pengaruh yang signifikan terhadap pertumbuhan ekonomi sehingga hipotesis pertama $\left(\mathrm{H}_{1}\right)$ diterima. Sedangkan, nilai t hitung dari variabel pengeluaran pemerintah $\left(\mathrm{X}_{2}\right)$ adalah 3,926> dibandingkan nilai t tabel yaitu 1,979 dengan signifkansi sebesar 0,000 yang lebih kecil dari signifikansi 0,05. Hal tersebut menunjukkan bahwa variabel pengeluaran pemerintah memiliki pengaruh yang signifikan terhadap pertumbuhan ekonomi sehingga hipotesis kedua $\left(\mathrm{H}_{2}\right)$ diterima. Sementara, nilai t hitung dari variabel kapasitas fiskal $\left(\mathrm{X}_{1}\right)$ adalah $-1,786$ < dibandingkan nilai t tabel yaitu $-1,979$ dengan signifkansi sebesar 0,077 yang lebih besar dari signifikansi 0,05. Hal tersebut menunjukkan bahwa variabel kapasitas fiskal tidak memiliki pengaruh yang signifikan terhadap indeks pembangunan manusia sehingga hipotesis ketiga $\left(\mathrm{H}_{3}\right)$ ditolak. Sedangkan, nilai $t$ hitung dari variabel pengeluaran pemerintah $\left(\mathrm{X}_{2}\right)$ adalah 1,416 < dibandingkan nilai $\mathrm{t}$ tabel yaitu 1,979 dengan signifkansi sebesar 0,160 yang lebih besar dari signifikansi 0,05. Hal tersebut menunjukkan bahwa variabel pengeluaran pemerintah tidak memiliki pengaruh yang signifikan terhadap indeks pembangunan manusia sehingga hipotesis keempat $\left(\mathrm{H}_{4}\right)$ ditolak. Sedangkan, nilai $\mathrm{t}$ hitung dari variabel pertumbuhan ekonomi $\left(\mathrm{Y}_{1}\right)$ adalah 3,654 > dibandingkan nilai $\mathrm{t}$ tabel yaitu 1,979 dengan signifkansi sebesar 0,000 yang lebih kecil dari signifikansi 0,05 . Hal tersebut menunjukkan 
bahwa variabel pertumbuhan ekonomi memiliki pengaruh yang signifikan terhadap indeks pembangunan manusia sehingga hipotesis kelima $\left(\mathrm{H}_{5}\right)$ diterima.

Variabel kapasitas fiskal memiliki pengaruh signifikan secara tidak langsung terhadap indeks pembanngunan manusia yang dapat dilihat dari nilai pengaruh langsung yaitu $-0,173$ yang lebih kecil dari pengaruh tidak langsung melalui pertumbuhan ekonomi yaitu -0,174. Hal ini menunjukkan bahwa variabel pertumbuhan ekonomi mampu memoderisasi hubungan antara kapasitas fiskal terhadap indeks pembangunan manusia sehingga hipotesis keenam $\left(\mathrm{H}_{6}\right)$ diterima. Demikian juga dengan variabel pengeluaran pemerintah memiliki pengaruh signifikan secara tidak langsung terhadap indeks pembanngunan manusia yang dapat dilihat dari nilai pengaruh langsung yaitu 0,109 yang lebih kecil dari pengaruh tidak langsung melalui pertumbuhan ekonomi yaitu 0,117 . Hal ini menunjukkan bahwa variabel pertumbuhan ekonomi mampu memoderisasi hubungan antara pengeluaran pemerintah terhadap indeks pembangunan manusia sehingga hipotesis ketujuh $\left(\mathrm{H}_{7}\right)$ diterima.

\section{PEMBAHASAN}

\subsection{Pengaruh Kapasitas Fiskal dan Pengeluaran}

Pemerintah Terhadap Pertumbuhan Ekonomi

Hasil analisis menunjukkan bahwa kapasitas fiskal memiliki pengaruh yang signifikan terhadap pertumbuhan ekonomi di Provinsi Kalimantan Tengah namun dengan arah yang negatif dalam periode tahun 2010-2017. Hasil ini memberikan informasi bahwa dengan semakin meningkatnya kapasitas fiskal maka pertumbuhan akan mengalami penurunan, demikian juga sebaliknya dengan semakin menurunnya kapasitas fiskal, maka pertumbuhan ekonomi akan semakin meningkat. Hasil ini tidak sejalan dengan konsep yang dikemukakan oleh Todaro (2000) bahwa dengan semakin tinggi kapasitas fiskal akan memiliki pengaruh yang signifikan terhadap peningkatan pertumbuhan ekonomi. Kondisi ini disebabkan oleh fakta empiris yang ada dimana dalam periode tahun 2010-2017 kapasitas fiskal menunjukkan penurunan dari 1,47 (2010) yang termasuk kategori indeks kapasitas tinggi, menurun menjadi 0,61 (2017) yang termasuk kategori derah dengan indeks kapasitas fiskal sedang. Hasil ini sejalan dengan penelitian terdahulu yang dilakukan oleh Zhang dan Zou (1998) dan Hendri (2015) bahwa desentralisasi fiskal berpengaruh negatif terhadap pertumbuhan ekonomi.

Hasil analisis menunjukkan bahwa pengeluaran pemerintah memiliki pengaruh yang signifikan terhadap pertumbuhan ekonomi di Provinsi Kalimantan Tengah dalam periode tahun 2010-2017. Hasil ini memberikan informasi bahwa dengan semakin meningkatnya pengeluaran pemerintah, maka pertumbuhan akan mengalami peningkatan, demikian juga sebaliknya. Hasil ini sejalan dengan konsep yang dikemukakan oleh Musgrave dan Musgrave (1980) dalam Arsyad (2010) bahwa kebijakan anggaran (budget policy) dapat memberikan dampak terhadap suatu sistem perekonomian melalui tiga komponen utama, yaitu perpindahan sumber daya (resources transfer), distribusi pendapatan (incident) dan pemisahan terhadap output (output effect). Artinya bahwa kebijakan anggaran yang dilakukan oleh pemerintah dapat berpengaruh terhada alokasi input dalam suatu perekonomian. Kondisi ini disebabkan oleh fakta empiris yang ada dimana dalam periode tahun 2010-2017, meskipun pengeluaran pemerintah melalui belanja modal menunjukkan trend fluktuatif, dimana dari tahun 2010 dengan realisasi pengeluaran sebesar Rp. 2,171 triliun meningkat menjadi Rp. 4,943 triliun (2015) dan melambat dengan terjadinya penurunan dari Rp. 4,488 triliun (2015) menjadi Rp. 4,023 (2017), namun secara umum alokasi belanja modal tersebut dapat dilakukan secara efektif dan tepat sasaran untuk ketersediaan layanan publik sehingga dapat memberikan dampak nyata terhadap peningkatan pertumbuhan ekonomi. Hasil ini sejalan dengan penelitian terdahulu yang dilakukan oleh oleh Sasana (2012), Ndakularak et al. (2013), Anitasari dan Soleh (2013), dan Maingi (2017) bahwa belanja pemerintah berpengaruh positif dan signifikan terhadap pertumbuhan ekonomi.

\subsection{Pengaruh Kapasitas Fiskal, Pengeluaran \\ Pemerintah dan Pertumbuhan Ekonomi Terhadap Kesejahteraan Masyarakat}

Hasil analisis menunjukkan bahwa kapasitas fiskal tidak memiliki pengaruh yang signifikan terhadap peningkatan indeks pembangunan manusia di Provinsi Kalimantan Tengah dalam periode tahun 2010-2017. Hasil ini sesuai dengan fakta empiris bahwa dengan kemandirian keuangan yang ada saat ini yang masih sangat bergantung pada topangan dana perimbangan dan PAD yang masih rendah menunjukkan perlunya upaya dalam peningkatan sumber penerimaan daerah seperti melakukan identifikasi potensi penerimaan baru yang belum tergali secara optimal dan melakukan inovasi peningkatan penerimaan pajak dan retribusi daerah. Hasil ini sejalan dengan penelitian terdahulu yang dilakukan oleh Widani dan Erawati (2016) menyimpulkan bahwa kapasitas fiskal tidak berpengaruh signifikan terhadap kesejahteraan masyarakat yang diproksi ke dalam Indeks Pembangunan Manusia (IPM).

Hasil analisis menunjukkan bahwa pengeluaran pemerintah tidak memiliki pengaruh yang signifikan terhadap pertumbuhan ekonomi di Provinsi Kalimantan Tengah dalam periode tahun 2010-2017. Hasil ini memberikan informasi bahwa dengan jumlah alokasi belanja daerah yang telah dikeluarkan ternyata masih belum mampu untuk meningkatkan kesejahteraan masyarakat yang di lihat dari capaian IPM. Fakta ini dapat di lihat dari trend realisasi belanja modal yang cenderung fluktuatif, dimana setelah terjadi peningkatan dari 2,171 
triliun (2010) meningkat menjadi Rp. 4,943 triliun (2015) dan melambat dengan terjadinya penurunan dari Rp. 4,488 triliun (2015) menjadi Rp. 4,023 (2017). Penyebab lainnya adalah alokasi yang tidak efektif dan tepat saran sehingga tidak benar-benar memberikan manfaat untuk ketersediaan layanan publik. Hasil ini sejalan dengan penelitian terdahulu yang dilakukan oleh Olopade dan Olopade (2010), Iheanacho (2016), Sumardjoko (2017) dan Okombi (2018) memberikan kesimpulan bahwa pengeluaran pemerintah tidak memberikan pengaruh yang signifikan dan bahkan dapat berpengaruh negatif terhadap kesejahteraan masyarakat.

Hasil analisis menunjukkan bahwa pertumban ekonomi memiliki pengaruh yang signifikan terhadap pertumbuhan ekonomi di Provinsi Kalimantan Tengah dalam periode tahun 2010-2017. Hasil ini memberikan informasi bahwa dengan pertumbuhan ekonomi yang ada saat ini mampu untuk meningkatkan kesejahteraan masyarakat yang dapat di lihat dari capaian IPM. Fakta ini dapat di lihat dari trend pertumbuhan ekonomi yang meningkat stabil. Dari Rp. 56,531 triliun (2010) meningkat menjadi Rp. 88,812 triliun (2017) yang di ikuti oleh peningkatan IPM secara konstan dari 65,96 (2010) meningkat menjadi 69,79 (2017). Hasil ini sejalan dengan penelitian terdahulu yang dilakukan oleh Mirza (2012) dan Priambodo (2015) yang menyatakan bahwa pertumbuhan ekonomi berpengaruh positif dan signifikan terhadap IPM.

\subsection{Pengaruh Kapasitas Fiskal dan Pengeluaran Pemerintah Terhadap Indeks Pembangunan Manusia Melalui Pertumbuhan Ekonomi}

Hasil analisis menunjukkan bahwa pertumbuhan ekonomi mampu memoderisasi hubungan antara kapasitas fiskal dengan indeks pembangunan manusia secara tidak langsung. Hal ini menunjukkan bahwa kapasitas fiskal mampu meningkatkan indeks pembangunan manusia di Provinsi Kalimantan Tengah dalam periode tahun 2010-2017 melalui pertumbuhan ekonomi. Hasil ini sesuai dengan hasil penelitian bahwa apabila kapasitas fiskal tidak berpengaruh secara langsung terhadap peningkatan IPM tetapi ketika melalui pertumbuhan ekonomi dapat memberikan dampak signifikan terhadap peningkatan kesejahteraan masyarakat melalui IPM. Hal ini menunjukkan bahwa dengan keberadaan fiskal yang ada saat ini apabila dapat dikelola dengan baik dan efektif serta efisien dengan peruntukkan yan tepat dapat menstimulasi peningkatan pertumbuhan ekonomi daerah yang pada akhirnya dapat meningkatkan kesejahteraan masyarakat melalui peningkatan capaian IPM.

Hasil analisis juga menunjukkan bahwa pengeluaran pemerintah yang di proksi melalui belanja modal mampu meningkatkan capaian IPM melalui pertumbuhan ekonomi. Hal ini menunjukkan bahwa pertumbuhan ekonomi mampu memoderisasi hubungan antara pengeluaran pemerintah dengan IPM secara tidak langsung. Hal ini menunjukkan bahwa pengeluaran pemerintah mampu meningkatkan IPM di Provinsi Kalimantan Tengah dalam periode tahun 2010-2017 melalui pertumbuhan ekonomi. Hasil ini sesuai dengan hasil penelitian bahwa apabila kapasitas fiskal tidak memiliki pengaruh secara langsung terhadap peningkatan IPM tetapi ketika melalui pertumbuhan ekonomi dapat memberikan dampak signifikan terhadap peningkatan IPM. Hal ini menunjukkan bahwa dengan alokasi pengeluaran pemerintah yang ada saat ini apabila dapat dikelola dengan baik dan efektif serta efisien dengan peruntukkan yan tepat dapat menstimulasi peningkatan pertumbuhan ekonomi daerah yang pada akhirnya dapat meningkatkan kesejahteraan masyarakat melalui peningkatan capaian IPM.

\section{KETERBATASAN STUDI}

Penelitian ini masih memiliki keterbatasan akan ketersediaan data periode penelitian yang masih singkat, yaitu dalam rentang waktu antara tahun 2010-2017 atau dalam kurun waktu tujuh tahun terakhir dan masih terbatas pada dua variabel bebas, yaitu kapasitas fiskal dan pengeluaran pemerintah. Untuk itu diharapkan agar penelitian lebih lanjut dapat menggunakan rentang waktu penelitian yang lebih lama serta dapat dengan menambah jumlah variabel bebas agar di peroleh analisis data secara detail dari wilayah yang dijadikan lokasi penelitian.

\section{KESIMPULAN DAN IMPLIKASI}

Berdasarkan hasil penelitian dan kajian empiris sebelumnya yang relevan dengan penelitian yang dilakukan, maka diperoleh beberapa kesimpulan penelitian. Secara langsung, variabel kapasitas fiskal dan pengeluaran pemerintah memiliki dampak yang besar terhadap peningkatan pertumbuhan ekonomi. Sementara, kapasitas fiskal dan pengeluaran pemeritnah tidak memiliki pengaruh yang nyata terhadap peningkatan IPM, sedangkan pertumbuhan ekonomi memiliki pengaruh yang besar terhadap peningkatan IPM. Secara tidak langsung, variabel kapasitas fiskal dan pengeluaran pemerintah memiliki pengaruh yang signiifikan terhadap IPM melalui pertumbuhan ekonomi pada Kabupaten/Kota di Provinsi Kalimantan Tengah tahun 2010-2017.

Sebagi implikasi dari temuan ini, pemerintah disarankan untuk meningkatkan sumber-sumber penerimaan daerah seperti melakukan identifikasi sumber-sumber penerimaan baru dan melakukan inovasi dalam bidang penerimaan pajak dan retribusi daerah secara optimal sebagai sumber endapatan daerah yang akan digunakan untuk belanja derah secara efektif dan tepat sasaran untuk peningkatan ertumbuhan ekonomi daerah dengan tujuan akhir berupa peningkatan kesejahteraan masyarakat melalui capaian IPM. 


\section{DAFTAR PUSTAKA}

Amanda, I.F. 2017. Pengaruh Kapasitas Fiskal dan Belanja Modal terhadap Pertumbuhan Ekonomi di Kabupaten/Kota Provinsi Lampung Tahun 2011-2015. Skripsi. Fakultas Ekonomi dan Bisnis, Universitas Lampung, Bandar Lampung.

Anitasari, M. and Soleh, A., 2015. Pengaruh Pengeluaran Pemerintah Terhadap Pertumbuhan Ekonomi di Provinsi Bengkulu. Ekombis Review, 3(2), 117-127

Arsyad, L. 2010. Ekonomi Pembangunan. Yogyakarta: UPP STIM YKPN.

Badan Pusat Statistik. 2018. Provinsi Kalimantan Tengah Dalam Angka 2018. BPS Provinsi Kalimantan Tengah.

Badan Pusat Statistik. 2015. Indeks Pembangunan Manusia 2014. Badan Pusat Statistik.

Banga, W. 2017. Administrasi Keuangan Negara dan Daerah: Konsep, Teori, dan Fenomena di Era Otonomi Daerah. Cetakan ke-1, Bogor: Ghalia Indonesia.

Gavriluţă, A.F. and Oprea, F., 2017. Fiscal Decentralization Determinants and Local Economic Development in EU Countries. European Union at Crossroads Building Resilience in Times of Change, 180-197.

Gunawan, I. 2017. Pengantar Statistika Inferensial. Cetakan ke-2. Jakarta: Rajawali Pers.

Hendri. 2015. Fiscal Decentralization and Regional Economic Growth in Sumatera, Indonesia. International Institute of Social Studies, 1-35.

Iheanacho, E., 2016. The contribution of government expenditure on economic growth of Nigeria disaggregated approach. International Journal of Economics and Management Sciences, 5(5), 1-8.

Iskandar, M.A. 2012. Pengaruh Belanja Modal, Dana Perimbangan, dan Kemandirian Fiskal terhadap Pertumbuhan Ekonomi Daerah (Studi Empiris pada Pemerintah Kabupaten/ Kota di Pulau Jawa Periode 2006-2010). Skripsi. Fakultas Ekonomi, Program Ekstensi Akutansi, Universitas Indonesia.

Jhingan, M.L. 2014. Ekonomi Pembangunan dan Perencanaan. Edisi 1, Cetakan ke-16. Jakarta: Rajawali Pers.

Lin, J.Y. and Liu, Z., 2000. Fiscal decentralization and economic growth in China. Economic development and cultural change, 49(1), 1-21.

Maingi, J.N. 2017. The Impact of Government Expenditure on Economic Growth in Kenya: 1963-2008. Advances in Economics and Business 5(12), 635-662.

Mirza, D.S., 2012. Pengaruh kemiskinan, pertumbuhan ekonomi, dan belanja modal terhadap indeks pembangunan manusia di Jawa Tengah tahun 20062009. Economics Development Analysis Journal, 1(2), 1 -15 .

Ndakularak, E., Setiawina, N.D. and Djayastra, I.K., 2014. Analisis Faktor-Faktor yang Mempengaruhi Kesejahteraan Masyarakat Kabupaten/Kota di Provinsi Bali. E-Jurnal Ekonomi dan Bisnis Universitas Udayana, 3(3), 140-153.
Okombi, I.F. 2018. The Impact of Government Expenditure on Economic Growth in Congo. International Economic Research, 9(1), 19-36.

Olopade, B.C. and Olopade, D.O., 2010. The impact of government expenditure on economic growth and development in developing countries: Nigeria as a case study. Department of Economics, Igbinedion University Okada, Edo State, Nigeria. 1-18.

Priambodo, A. and Noor, I., 2016. Analisis Pengaruh Belanja Pemerintah Daerah Terhadap Indeks Pembangunan Manusia (Studi pada Kabupaten/Kota di Pulau Jawa Tahun 2007-2013). Jurnal Ilmiah Mahasiswa FEB, 3(2),1-13.

Putra, W. 2018. Tata Kelola Ekonomi Keuangan Daerah. Edisi 1 Cetakan ke-1, Jakarta: Rajawali Pers.

Sanjaya, M.W., Sudirman, I.W. and Budiasa, I.G.S., 2017. Pengaruh Pendalaman Finansial dan Keterbukaan Perdagangan terhadap Pertumbuhan Ekonomi Provinsi Bali. Buletin Studi Ekonomi, 78-88.

Sasana, H., 2006. Analisis dampak desentralisasi fiskal terhadap pertumbuhan ekonomi di kabupaten/kota provinsi Jawa Tengah. Jurnal Dinamika Pembangunan (JDP), 3(2), 146-170.

Sasana, H., 2016. Pengaruh Belanja Pemerintah Daerah Dan Pendapatan Perkapita Terhadap Indeks Pembangunan Manusia (Studi Kasus Di Kabupaten/ Kota Provinsi Jawa Tengah). Media Ekonomi dan Manajemen, 25(1),1-12.

Sukirno, S. 2015. Makroekonomi Teori Pengantar. Edisi Ketiga. Cetakan Ke-23. Jakarta: Rajawali Pers.

Sumardjoko, I. 2017. Analisis Efisiensi Belanja Langsung Melalui Penguatan Belanja Modal Daerah dan Implikasinya Terhadap Pertumbuhan Ekonomi Regional, Jurnal Defis, 1(1), 71-90.

Sunarni. 2017. Pengaruh Belanja Daerah terhadap Indeks Pembangunan Manusia di Kabupaten/Kota SeIndonesia. Tesis. Program Pascasarjana Magister IImu Akuntansi Fakultas Ekonomi dan Bisnis Universitas Lampung, Bandar Lampung.

Surtikanti. 2004. Permasalahan Otonomi Daerah ditinjau dari Aspek Perimbangan Keuangan Pemerintah Pusat dan Daerah. Majalah Ilmiah UNIKOM, 11(1), 15-30.

Todaro, M.P., Smith, S.C. 2011. Pembangunan Ekonomi. Jilid 1 Edisi Kesebelas. Jakarta: Penerbit Erlangga.

Widani, C.I.K., and Erawati, N.M.A. 2016. Pengaruh Kapasitas Fiskal Daerah Dan Pertumbuhan Ekonomi Daerah Pada Indeks Pembangunan Manusia. E-Jurnal Akuntansi, 17(1), 203-232.

Zhang, T. and Zou, H.F., 1998. Fiscal decentralization, public spending, and economic growth in China. Journal of public economics, 67(2), 221-240. 